\title{
PENGARUH MEDIA AUDIOVISUAL TERHADAP PENGUASAAN KOSAKATA BAHASA INGGRIS SISWA KELAS III SEKOLAH DASAR
}

\section{Githa S.I. Fa Biola dan Mersilina L. Patintingan}

Universitas Kristen Indonesia Toraja

Email: ukitoraja@yahoo.com

\section{Info Artikel}

Sejarah Artikel:

Diserahkan 26 Januari 2021

Direvisi 15 April 2021

Disetujui 15 April 2021

\section{Keywords:}

Audiovisual media

english vocabulary mastery level

\section{Abstract}

This study examined the influence of the use of audiovisual media on the level of English vocabulary mastery of grade 3 students at SDN 130 Tokesan Tana Toraja Regency.

The approach used in this research is quantitative approach with one group pretest posttest design. Data analysis technique used in this study is using t-test formula.

Based on the results of the study obtained showed that with the value of significance of t-test results less than 0.05 is 0.000 , and the result of $t$ calculate greater than t table is $t$ count with a value of 6704 greater than the table $t$ value of 2,093, it can be concluded that there is an influence of the use of audiovisual media on the level of Mastery of English vocabulary of grade III students sdn 130 Tokesan Tana Toraja

\section{Abstrak}

Penelitian ini menelaah pengaruh penggunaan media audiovisual terhadap tingkat penguasaan kosakata bahasa Inggris siswa kelas III SDN 130 Tokesan Kabupaten Tana Toraja.

Dengan pendekatan kuantitatif dan jenis penelitian ekperimen kelompok tunggal (one group pretest posttest design). Teknik analisis data yang digunakan dalam penelitian ini adalah uji $t$ test.

Hasil penelitian diperoleh bahwa nilai signifikansi hasil uji t-test lebih kecil dari 0.05 yaitu 0.000 , dan hasil t hitung yang lebih besar dari t tabel yaitu t hitung dengan nilai 6.704 lebih besar dari nilai t tabel yaitu 2.093. Dengan demikian disimpulkan bahwa terdapat pengaruh penggunaan media audiovisual terhadap tingkat penguasaan kosakata bahasa Inggris siswa kelas III SDN 130 Tokesan Kabupaten Tana Toraja. 


\section{Githa S.I. Fa Biola, dan Mersilina L. Patintingan \\ PENGARUH MEDIA AUDIOVISUAL TERHADAP PENGUASAAN KOSAKATA BAHASA .... WASIS: Jurnal Ilmiah Pendidikan. Volume 2, Nomor 1, Mei 2021, hlm. 48-54}

\section{PENDAHULUAN}

Bahasa Inggris merupakan salah satu bahasa internasional dan menjadi alat komunikasi di dunia. Bahkan kemungkinan besar bahasa Inggris menjadi bahasa dasar peradaban dunia (Izzan, 2010). Karena bahasa Inggris menjadi bahasa internasional, bahasa Inggris pun menjadi bahasa yang banyak diminati sekarang ini. Banyak siswa yang mengikuti kursus-kursus demi menambah kemampuannya dalam berbahasa Inggris.

Izzan (2010) mengungkapkan bahwa pembelajaran bahasa Inggris di sekolah mencakup komponen-komponen bahasa yang berupa keterampilan menyimak (listening), membaca (reading), berbicara (speaking) dan mengarang (writing). Untuk bisa meningkatkan empat kemampuan tersebut maka terlebih dahulu harus memperkaya kosakata atau vocabulary. Dalam pembelajaran yang mencakup empat komponen tersebut siswa harus memiliki perbendaharaan kosakata yang baik. Kosakata merupakan himpunan kata yang diketahui atau dimengerti oleh seseorang dan akan digunakan untuk menyusun kalimat baru. Oleh karena itu, pentinglah bagi setiap siswa untuk belajar kosakata sejak dini.

Sejalan dengan itu, mata pelajaran bahasa Inggris juga diajarkan di Sekolah Dasar untuk mengenalkan pada anak bahasa Inggris sejak dini. Bahasa Inggris di Sekolah Dasar merupakan mata pelajaran muatan lokal yang bertujuan agar peserta didik dapat mengembangkan kompetensi berkomunikasi dan memiliki kesadaran tentang hakikat dan pentingnya Bahasa Inggris untuk meningkatkan daya saing bangsa dalam masyarakat global. Namun dalam pembelajaran, siswa seringkali terhambat karena media pembelajaran yang tidak mendukung dan kurang menyenangkan (Arsyad, 2017). Media pembelajaran yang tidak mendukung dan kurang menyenangkan berakibat pada tidak tertariknya siswa belajar bahasa Inggris dan membuat hasil belajar yang tidak mencapai Kriteria Ketuntasan Minimal (KKM).

Berdasarkan hasil observasi diketahui bahwa dari 20 siswa kelas III di SDN 130 Tokesan, hanya 12 orang yang nilainya mencapai Kriteria Ketuntasan Minimal (KKM). Sisanya yaitu 8 orang, masih belum mencapai nilai Kriteria Ketuntasan Minimal (KKM) yang diisyaratkan yaitu nilai 60. Dari hasil dari evaluasi belajar siswa yang tidak mencapai Kriteria Ketuntasan Minimal (KKM) diketahui bahwa penguasaan kosakata bahasa Inggris siswa rendah. Hal tersebut berdasarkan dari 15 soal yang berikan, terdapat 13 soal untuk menguji pengetahuan tentang kosakata bahasa Inggris. Rendahnya penguasaan kosakata Bahasa inggris dikarenakan kurang adanya penggunaan media pembelajaran yang menarik. Karena faktor tersebut maka guru hendaknya menggunakan media agar siswa tertarik mempelajari bahasa dan memengaruhi tingkat penguasaan kosakata bahasa Inggris baik.

Dalam pembelajaran Bahasa Inggris di Sekolah Dasar pemanfaatan media audiovisual cenderung sangat diperlukan. Hal ini disebabkan oleh cara belajar siswa yang lebih cocok untuk mengaktualisasikan bahasa yang dipelajari dalam bentuk benda nyata. Bagi kebanyakan siswa dalam mempelajari kosakata bahasa Inggris akan sangat sulit apabila hanya dikatakan atau diajarkan dalam bentuk verbal yang bersifat abstrak. Siswa akan lebih mudah mempelajari kata-kata tertentu apabila dibantu dengan alat pandang dengar yang nyata (Rusman, 2018). Oleh karena itu, media audiovisual merupakan salah satu media yang tepat untuk pembelajaran penguasaan kosakata bahasa Inggris.

Penelitian terdahulu juga memberikan informasi terkait penelitian ini yaitu penelitian Elviza (2013) yang menyebutkan bahwa dengan memberikan permainan teka-teki silang siswa kelas VII memiliki peningkatan kosakata bahasa Inggris, dimana dengan memberikan berbagai macam variasi permainan siswa dengan mudah dapat mengingat kembali setiap kosakata yang mungkin pernah dibaca dan menolongnya untuk menambah jumlah kosakata.

Fitriyani (2017) dalam hasil penelitiannya memaparkan bahwa Media Flash Cards pun dapat dengan efektif meningkatkan pemahaman kosakata Bahasa Inggris siswa kelas 3 SD. Media Flash Cards ini lebih menolong siswa dalam mengenal kosakata baru. Pengenalan kosakata baru ini dilakukan menggunakan Flash Card berisi gambar yang sangat membantu siswa untuk mengasosiasikan kata asing tersebut dengan benda konkret yang sering mereka lihat dalam keseharian.

Nurfadilah (2018) mendukung asumsi peneliti bahwa Penguasaan kosakata anak tuna rungu sangat terbantu dengan adanya Media pembelajaran Video Komunikasi Total, dimana siswa yang mengalami kesulitan mendengar dapat dibantu secara visual dengan komunikasi khusus untuk siswa tuna rungu.

Media audivisual ini berisi gambaran dan deskripsi sebuah benda yang dipadukan dengan huruf yang memungkinkan mereka dapat belajar dengan cukup cepat. Media audiovisual yang 


\section{Githa S.I. Fa Biola, dan Mersilina L. Patintingan \\ PENGARUH MEDIA AUDIOVISUAL TERHADAP PENGUASAAN KOSAKATA BAHASA .... WASIS: Jurnal Ilmiah Pendidikan. Volume 2, Nomor 1, Mei 2021, hlm. 48-54}

digunakan dalam penelitian ini berisi dialog interaktif pembelajaran kosakata yang memperkenalkan siswa kosakata baru. Selain itu, media audiovisual ini juga berisi instruksi dan latihan bagi siswa melalui pengulangan bunyi, pemaknaan leksikal dan aplikasi ragam bahasa yang sangat memungkinkan siswa tidak hanya mendengar tetapi juga melibatkan aktivitas menyimak, berbicara, membaca dan menulis. Hal tersebut diharapkan dapat membuat siswa memiliki variasi aktivitas belajar yang beragam, sehingga tidak hanya dapat meningkatkan penggunaan kosakata tetapi juga mendukung keaktifan belajar siswa.

Tujuannya dalam penelitian ini adalah menelaah pengaruh penggunaan media audiovisual terhadap tingkat penguasaan kosakata bahasa Inggris siswa kelas III SDN 130 Tokesan Kabupaten Tana Toraja.

\section{METODE PENELITIAN}

Penelitian adalah penelitian kuantitatif dengan ariabel bebas dalam penelitian penelitian in adalah media audiovisual, sedangkan variabel terikat dalam penelitian ini adalah tingkat penguasaan kosakata bahasa Inggris. Penelitian ini menggunakan desain eksperimen kelompok tunggal (one group pretest posttest design). Eksperimen kelompok tunggal (one group pretest posttest design) menerapkan pretest dan posttest pada satu kelompok dengan memberikan perlakuan pretest kemudian mengamati efeknya/ posttest pada variabel terikat.

Kelas eksperimen diberikan perlakuan yaitu pembelajaran dengan menggunakan media audiovisual. Pretest (tes awal) diberikan sebelum pembelajaran untuk mengetahui sejauh mana kemampuan atau penguasaan siswa terhadap materi yang akan diberikan. Selanjutnta posttest (tes akhir) diberikan setelah pembelajaran untuk mengetahui pengaruh media audiovisual terhadap variabel terikat.

Populasi dalam penelitian ini adalah semua siswa kelas III SDN 130 Tokesan yang berjumlah 20 orang. Sampel dalam penelitian ini adalah purposive sampling. Purposive sampling adalah teknik penentuan sampel yang berdasarkan pertimbangan pelaku riset atau dengan maksud dan tujuan penelitian (Sukandarrumidi, 2012). Lebih lanjut Sukandarrumidi (2012) menjelaskan bahwa purposive sampling disesuaikan dengan tujuan penelitian dan jumlah atau ukuran sampel tidak dipersoalkan. Sampel penelitian ini yaitu siswa kelas III SDN 130 Tokesan yang berjumlah 20 orang.
Teknik pengumpulan data menggunakan teknik tes dengan instrument berupa soal pretest dan posttest. Teknik analisis data menggunakan uji t-test. Uji tersebut digunakan untuk menghitung keefektivitasan perlakuan yang diberikan kepada subjek penelitian. Hasil data inilah yang kemudian dianalisis sehingga hasil yang diperoleh dapat menunjukkan perlakuan yang diberikan efektif atau tidak. Teknik analisis data yang digunakan dalam penelitian ini adalah menggunakan SPSS dan rumus t-test dengan rumus sebagai berikut:

$$
t=\frac{M D}{\sqrt{\frac{\sum D 2-\frac{(\Sigma D)^{2}}{N}}{N(N-1)}}}
$$

Keterangan:

MD : Perbedaan rata-rata (jumlah perbedaan dibagi jumlah data)

$\mathrm{N} \quad$ : Jumlah data (individu)

D : Jumlah nilai pretest

D2 : Jumlah nilai posttest

\section{HASIL DAN PEMBAHASAN}

Penelitian ini dilakukan dengan langkahlangkah atau skenario pembelajaran menggunakan media audiovisual. Adapun langkah-langkah tersebut adalah sebagai berikut:

a. Mempersiapkan kelas, dalam hal ini siswa terlebih dahulu dipersiapkan untuk mengikuti pembelajaran.

b. Mempersiapkan alat bantu yang akan digunakan dalam pembelajaran (pengeras suara, proyektor, layar proyektor, dan tempat proyektor).

c. Pemutaran media audiovisual (video/tayangan).

d. Penguatan (tanya jawab, diskusi) terhadap materi yang disediakan melalui video/tayangan.

e. Kesimpulan.

Setelah pembelajaran dengan menggunakan media audiovisual, siswa diberikan tes untuk menguji penguasaan kosakata selama empat kali pertemuan. Adapun rekapitulasi hasil tes siswa selama empat kali pertemuan disajikan dalam Tabel 1 berikut ini.

Tabel 1. Rekapitulasi Nilai Tes siswa kelas III SDN 130 Tokesan

\begin{tabular}{lccccc}
\hline \multirow{2}{*}{ No Nama } & \multicolumn{5}{c}{ Pertemuan } \\
\cline { 2 - 5 } & & I & 2 & 3 & 4 \\
\hline
\end{tabular}


Githa S.I. Fa Biola, dan Mersilina L. Patintingan

PENGARUH MEDIA AUDIOVISUAL TERHADAP PENGUASAAN KOSAKATA BAHASA .... WASIS: Jurnal Ilmiah Pendidikan. Volume 2, Nomor 1, Mei 2021, hlm. 48-54

\begin{tabular}{cccccc}
\hline 1 & Cristian & 80 & 60 & 70 & 70 \\
2 & Agung & 100 & 80 & 90 & 80 \\
3 & Heri & 70 & 60 & 60 & 80 \\
4 & Homer & 70 & 80 & 70 & 80 \\
5 & Aldianto & 70 & 80 & 60 & 90 \\
6 & Cristyano & 90 & 80 & 70 & 100 \\
7 & Elaine & 100 & 100 & 100 & 90 \\
8 & Maykel & 80 & 100 & 70 & 90 \\
9 & Gishela & 90 & 100 & 100 & 90 \\
10 & Febi & 70 & 80 & 90 & 90 \\
11 & Fransiskus & 70 & 80 & 90 & 100 \\
12 & Julianti & 90 & 100 & 90 & 100 \\
13 & Yeriel & 100 & 100 & 100 & 100 \\
14 & Gizela & 100 & 100 & 90 & 100 \\
15 & Regal & 70 & 80 & 70 & 70 \\
16 & Intan & 60 & 60 & 70 & 70 \\
17 & Vargas & 60 & 60 & 70 & 80 \\
18 & Ariel & 60 & 80 & 70 & 80 \\
19 & Narasya & 70 & 60 & 80 & 70 \\
20 & Rendi & 70 & 60 & 60 & 70 \\
\hline
\end{tabular}

Selanjutnya untuk mengetahui pengaruh penggunaan media audiovisual, maka siswa diberikan diberikan pretest sebelum dilakukan pembelajaran dengan menggunakan media audiovisual. Tujuan pemberian pretest ini untuk mengetahui kemampuan awal siswa terkait denfan penguasaan kosakata Bahasa Inggris. Setelah siswa mengerjakan pretest, selanjutnya siswa melakukan pembelajaran dengan menggunakan media audiovisual. Setelah kelas eksperimen diberikan perlakuan (pembelajaran dengan media audiovisual), maka dilanjutkan dengan memberikan posttest untuk mengetahui kemampuan akhir siswa terkait dengan penguasaan kosakata Bahasa Inggris. Instrumen soal pretest dan posttest sebelumnya sudah divalidasi oleh ahli. Hasil rekapitulasi nilai dari pretest dan posttest disajikan pada Tabel 2 berikut ini.

Tabel 2. Rekapitulasi Nilai Pretest dan Posttest

\begin{tabular}{clcc}
\hline No & \multicolumn{1}{c}{ Nama } & $\begin{array}{c}\text { Nilai } \\
\text { Pretest }\end{array}$ & $\begin{array}{c}\text { Nilai } \\
\text { Posttest }\end{array}$ \\
\hline 1 & Cristian & 20 & 40 \\
2 & Agung & 63 & 63 \\
3 & Heri & 20 & 43 \\
4 & Homer & 56 & 50 \\
5 & Aldianto & 50 & 63 \\
6 & Cristyano & 46 & 70 \\
7 & Elaine & 70 & 96 \\
8 & Maykel & 23 & 60 \\
9 & Gishela & 53 & 80 \\
10 & Febi & 23 & 43 \\
11 & Fransiskus & 36 & 63 \\
12 & Julianti & 76 & 73 \\
\hline
\end{tabular}

\begin{tabular}{llcc}
\hline 13 & Yeriel & 80 & 100 \\
14 & Gizela & 83 & 96 \\
15 & Regal & 30 & 53 \\
16 & Intan & 33 & 40 \\
17 & Vargas & 20 & 40 \\
18 & Ariel & 43 & 56 \\
19 & Narasya & 23 & 36 \\
20 & Rendi & 30 & 40 \\
\hline
\end{tabular}

Hasil pretest dan posttest sebelum dilakukan uji $t$-test untuk mengetahui apakah ada pengaruh penggunaan media audiovisual terhadap tingkat penguasaan kosakata bahasa Inggris siswa kelas III SDN 130 Tokesan Kabupaten Tana Toraja, terlebih dahulu dilakukan uji normalitasnya. Uji normalitas dilakukan untuk mengetahui apakah data nilai pretest dan posttest terdistribusi normal atau tidak.

Untuk mengetahui nilai pretest dan posttest terdistribusi normal atau tidak, digunakan uji kolmogorov-smirnov melalui aplikasi SPSS. Hasil uji normalitas disajikan pada Tabel 3 berikut.

Tabel 3. Tabel Uji Normalitas Nilai Pretest dan Posttest

\begin{tabular}{|c|c|c|c|}
\hline \multicolumn{4}{|c|}{ One-Sample Kolmogorov-Smirnov Test } \\
\hline & & Pretest & Posttest \\
\hline \multicolumn{2}{|l|}{$\mathrm{N}$} & 20 & 20 \\
\hline \multirow{2}{*}{$\begin{array}{l}\text { Normal } \\
\text { Parameters }{ }^{a, b}\end{array}$} & Mean & 43.90 & 60.25 \\
\hline & \begin{tabular}{|l} 
Std. \\
Deviation \\
\end{tabular} & 21.487 & 20.269 \\
\hline \multirow{3}{*}{$\begin{array}{l}\text { Most } \\
\text { Extreme } \\
\text { Differences }\end{array}$} & Absolute & .144 & .153 \\
\hline & Positive & .144 & .153 \\
\hline & Negative & -.133 & -.116 \\
\hline \multicolumn{2}{|l|}{ Test Statistic } & .144 & .153 \\
\hline \multicolumn{2}{|l|}{ 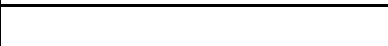 } & $.200^{\mathrm{c}, \mathrm{d}}$ & $.200^{\mathrm{c}, \mathrm{d}}$ \\
\hline
\end{tabular}

Berdasrakan Tabel 3 diketahui bahwa hasil dari uji normalitas data nilai pretest dan posttest adalah nilai signifikansi dari uji kolmogorov-smirnov sebesar $0.200>0.05$ sehingga data nilai pretest dan posttest berdistribusi normal. Selain itu dapat dilihat dari Asymp.Sig., uji normalitas juga dapat dilihat dari kolom Most Extreme Differences Absolute pada Tabel 3 yang dibandingkan dengan tabel nilai kritik uji kolmogorov-smirnov. Pada tabel nilai kritik uji kolmogorov-smirnov, jika sampel berjumlah 20, dengan confidence interval atau taraf kepercayaan penelitian 0.05 , maka taraf signifikasi D adalah 0.294. Apabila data 


\section{Githa S.I. Fa Biola, dan Mersilina L. Patintingan \\ PENGARUH MEDIA AUDIOVISUAL TERHADAP PENGUASAAN KOSAKATA BAHASA .... WASIS: Jurnal Ilmiah Pendidikan. Volume 2, Nomor 1, Mei 2021, hlm. 48-54}

berdistribusi normal, maka data harus kurang dari nilai 0.294. Pada kolom Most Extreme Differences Absolute, data nilai pretest bernilai 0.144 dan data nilai posttest bernilai 0.153 . Nilai kedua data tersebut kurang dari 0.294. Dengan demikian maka persyaratan atau asumsi normalitas sudah terpenuhi.

Setelah uji normalitas berhasil atau terpenuhi, maka dilakukan t-test untuk mengetahui apakah ada pengaruh penggunaan media audiovisual terhadap tingkat penguasaan kosakata bahasa Inggris siswa kelas III SDN 130 Tokesan Kabupaten Tana Toraja. Uji t-test dilakukan melalui aplikasi SPSS.

Menurut Santoso (2014:265), pedoman pengambilan keputusan dalam uji t-test berdasarkan signifikansi (Sig.) hasil output SPSS adalah sebagai berikut:

1. Jika nilai Sig. (2-tailed) lebih kecil dari 0.05, maka $\mathrm{H}_{0}$ ditolak dan $\mathrm{H}_{1}$ diterima.

2. Jika nilai Sig. (2-tailed) lebih besar dari 0.05, maka $\mathrm{H}_{0}$ diterima dan $\mathrm{H}_{1}$ ditolak.

Hipotesis dalam penelitian ini adalah sebagai berikut.

$\mathrm{H}_{0} \quad$ : Tidak ada pengaruh penggunaan media audiovisual terhadap tingkat penguasaan kosakata bahasa Inggris siswa kelas III SDN 130 Tokesan Kabupaten Tana Toraja.

$\mathrm{H}_{1} \quad$ : Ada pengaruh penggunaan media audiovisual terhadap tingkat penguasaan kosakata bahasa Inggris siswa kelas III SDN 130 Tokesan Kabupaten Tana Toraja.

Hasil uji t-test disajikan pada Tabel 4 berikut.

Tabel 4. Tabel Hasil Uji T-Test

\begin{tabular}{|c|c|c|c|c|c|}
\hline \multicolumn{6}{|c|}{ Paired Samples T-Test } \\
\hline & \multicolumn{5}{|c|}{ Paired Differences } \\
\hline & \multirow{2}{*}{ Mean } & \multirow{2}{*}{$\begin{array}{l}\text { td.Devi } \\
\text { ion }\end{array}$} & \multirow{2}{*}{\begin{tabular}{|l|} 
tdd. Erro \\
Mean
\end{tabular}} & \multicolumn{2}{|c|}{$\begin{array}{l}\text { 95\%Confidence Interva } \\
\text { of the Difference }\end{array}$} \\
\hline & & & & Lower & Upper \\
\hline \begin{tabular}{l|l} 
Pair 1 & retest- \\
& posttest
\end{tabular} & -16.350 & 10.908 & .439 & -21.455 & -11.245 \\
\hline
\end{tabular}

\begin{tabular}{|l|l|l|}
\hline $\mathrm{T}$ & $\mathrm{Df}$ & Sig.(2-tailed) \\
\hline-6.704 & 19 & .000 \\
\hline
\end{tabular}

Hasil uji t-test pada Tabel 4 diketahui bahwa Sig. (2-tailed) lebih kecil dari 0.05 sehingga $\mathrm{H}_{0}$ ditolak dan $\mathrm{H}_{1}$ diterima. Selain membandingkan antara nilai signifikansi (Sig.) probabilitas 0.05, dapat pula dilakukan perbandingan antara $\mathrm{t}$ hitung dan $\mathrm{t}$ tabel untuk pengujian hipotesis. Suharsaputra (2014) mengatakan bahwa apabila hasil t hitung lebih besar dari t tabel, maka perbedaan tersebut signifikan pada taraf tertentu.

Berdasarkan tabel hasil uji t-test, diketahui t hitung bernilai negatif yaitu sebesar -6.704. T hitung bernilai negatif tersebut disebabkan karena nilai rata-rata pretest lebih rendah dari nilai ratarata posttest. $\mathrm{T}$ hitung dalam tabel tersebut bermakna positif yaitu 6.704 .

Setelah mengetahui t hitung, selanjutnya adalah tahap mencari nilai t tabel yang sesuai. Dari tabel hasil uji t-test di atas, dapat dilihat bahwa $d f$ adalah 19. Pada t tabel, nilai dari signifikansi dengan $d f 19$ adalah 2.093. Dengan demikian, karena nilai t hitung yaitu 6.704 lebih besar dari nilai t tabel yaitu 2.093, maka $\mathrm{H}_{0}$ ditolak dan $\mathrm{H}_{1}$ diterima, sehingga dapat disimpulkan bahwa ada pengaruh penggunaan media audiovisual terhadap tingkat penguasaan kosakata bahasa Inggris siswa kelas III SDN 130 Tokesan Kabupaten Tana Toraja.

Hasil penelitian menunjukkan bahwa terdapat peningkatan dari nilai pretest dan posttest siswa. Peningkatan penguasaan kosakata Bahasa Inggris siswa ini dikarenakan penerapan media audiovisual. Hal tersebut sejalan dengan pendapat Lubis (2019) bahwa penggunaan media audiovisual dapat meningkatkan peningkatan kosakata anak. Menurut Haryoko (2019) media audiovisual membantu siswa dalam meningkatkan retensi (ingatan) karena kemampuan media audiovisual menyajikan gambar dan suara yang memberinya daya tarik sendiri sehingga menarik perhatian siswa dan melekat dalam ingatan siswa.

Dari hasil penelitian diatas memberikan informasi bahwa peningkatan tingkat penguasaan kosakata siswa yang dari hasil analisa soal yang hanya dapat menebak dan melengkapi kata yang tidak sempurna menjadi dapat memahami makna leksikalnya. Hal ini dibuktikan dengan hasil jawaban soal yang ingin mengungkapkan bagaimana siswa dapat memaknai kata tersebut dalam penggunaanya pad sebuah kalimat. Hal ini diindikasi dan dibuktikan dengan adanya perlakuan di tahap 3. Pemutaran Media audiovisual (interaktif) yang diikuti dengan adanya tahap 4. Penguatan dalam bentuk tanya jawab dan diskusi yang disediakan melalui video/tayangan tersebut memberi pengaruh yang signifikan terhadap peningkatan kosakata. Indikatornya siswa dapat membaca, menerka makna dari hasil simakan, menggunakannya dalam kalimat. Hali ini meningkatkan daya retensi (ingatan). Hal ini sejalan dengan pendapat Darma (2008) yang mengatakan jika dalam pembelajaran siswa diberi kesempatan untuk 


\section{Githa S.I. Fa Biola, dan Mersilina L. Patintingan \\ PENGARUH MEDIA AUDIOVISUAL TERHADAP PENGUASAAN KOSAKATA BAHASA .... WASIS: Jurnal Ilmiah Pendidikan. Volume 2, Nomor 1, Mei 2021, hlm. 48-54}

dapat menyimpulkan sendiri dan menyusun sendiri pengetahuan baru melalui pengalaman belajar yang bervariasi maka pembelajaran tersebut sudah berhasil.

Dalam pembelajaran, langkah guru dalam membuat siswa mudah memahami adalah ketika guru memutarkan video/tayangan. Siswa mudah memahami kosakata baru ketika guru memutarkan video/tayangan karena saat pemutaran video/tayangan. Senada dengan Ahsin (2016) menyatakan bahwa dengan menggunakan media audiovisual dapat membantu siswa dalam meningkatkan keterampilan menyimak dengan melihat gambar. Siswa dapat membaca kosakata tersebut, mendengarkan cara ucap kosakata tersebut, dan melihat contoh atau gambar dari kosakata baru yang ada dalam video/tayangan. Penggunaan media berbasis multimedia membuat siswa lebih senang dalam proses pembelajaran karena ada unsur gambar, tulisan, suara, maupun gerakan (Nikmah dkk, 2020). Setelah pemutaran video atau tayangan, langkah guru selanjutnya adalah mengucapkan materi dalam bahasa Inggris lalu diikuti oleh siswa. Pengucapan diulang hingga pengucapan siswa benar sesuai dengan video/tayangan yang telah ditayangkan (Rusmajadi, 2010). Langkah ini akan memberikan penguatan dalam ingatan siswa.

\section{SIMPULAN}

Hasil penelitian yang telah dilakukan tentang pengaruh penggunaan media audiovisual terhadap tingkat penguasaan kosakata bahasa Inggris siswa kelas III SDN 130 Tokesan Kabupaten Tana Toraja, maka dapat disimpulkan bahwa ada pengaruh penggunaan media audiovisual terhadap tingkat penguasaan kosakata bahasa Inggris siswa kelas III SDN 130 Tokesan Kabupaten Tana Toraja. Dari hasil analisis data yang ada juga menunjukkan bahwa ada pengaruh penggunaan media audiovisual terhadap tingkat penguasaan kosakata bahasa Inggris siswa kelas III SDN 130 Tokesan Kabupaten Tana Toraja. Hal ini ditunjukkan dengan nilai signifikansi hasil uji $t$-test lebih kecil dari 0.05 yaitu 0.000 , dan hasil $\mathrm{t}$ hitung yang lebih besar dari $\mathrm{t}$ tabel yaitu $\mathrm{t}$ hitung dengan nilai 6.704 lebih besar dari nilai $t$ tabel yaitu 2.093.

\section{DAFTAR PUSTAKA}

Ahsin, M. N. (2016). Peningkatan Keterampilan Menulis Karangan Narasi Dengan Menggunakan Media Audiovisual dan Metode Quantum Learning. Refleksi Edukatika: Jurnal Ilmiah Kependidikan, 6(2).
Arsyad, Azhar (Ed). 2017. Media Pembelajaran. Jakarta: Rajawali Press.

Darma, Surya. 2008. Kriteria dan Indikator Keberhasilan Pembelajaran. Jakarta: Departemen Pendidikan Nasional.

Elviza, Y., Emidar, E., \& Noveria, E. (2013). Peningkatan Penguasaan Kosakata Melalui Teknik Permainan Teka-teki Silang di Kelas VII. A SMPN 2 Sungai Penuh. Pendidikan Bahasa Indonesia, 1(2), 469-476.

Fitriyani, Eka dkk. 2017. Efektivitas Media Flash Cards dalam Meningkatkan Kosakata Bahasa Inggris. 4(2).

Haryoko, S. (2012). Efektivitas pemanfaatan media audio-visual sebagai alternatif optimalisasi model pembelajaran. Jurnal Edukasi Elektro, 5(1).

Izzan, Ahmad. 2010. Metodologi Pembelajaran Bahasa Inggris. Bandung: Humaniora.

Lubis, E., \& Yuniarni, D. Pengaruh Media Audio Visual Terhadap Peningkatan Kosakata Anak Usia 4-5 Tahun. Jurnal Pendidikan dan Pembelajaran Khatulistiwa, 3(8).

Nikmah, N., Rahayu, R., \& Fajrie, N. (2020). Penerapan Media Pembelajaran Math Mobile Learning Untuk Meningkatkan Kemampuan Pemecahan Masalah Siswa Kelas IV. WASIS: Jurnal Ilmiah Pendidikan, 1(2), 44-52.

Nurfadilah dan Nurhastuti. 2018. Media Pembelajaran Video Komunikasi Total Untuk Meningkatkan Penguasaan Kosakata Anak Tuna Rungu. 6(1)

Nurfadilah, N., \& Nurhastuti, N. (2018). Media Pembelajaran Video Komunikasi Total Untuk Meningkatkan Penguasaan Kosakata Anak Tunarungu. Jurnal Penelitian Pendidikan Khusus, 6(2), 230-237.

Rusmajadi, Jodih. 2010. Terampil Berbahasa Inggris Beberapa Tips Mengajar Bahasa Inggris. Jakarta: PT Indeks.

Rusman. 2018. Model-model Pembelajaran: Mengembangkan Profesionalisme Guru. Depok: Rajawali Pres. 
Githa S.I. Fa Biola, dan Mersilina L. Patintingan

PENGARUH MEDIA AUDIOVISUAL TERHADAP PENGUASAAN KOSAKATA BAHASA ....

WASIS: Jurnal Ilmiah Pendidikan. Volume 2, Nomor 1, Mei 2021, hlm. 48-54

Santoso, Singgih. 2014. Panduan Lengkap SPSS Versi 20 Edisi Revisi. Jakarta: PT Elex Media Komputindo.

Suharsaputra, Uhar. 2014. Metode Penelitian Kuantitatif, Kualitatif, dan Tindakan. Bandung: Refika Aditama.

Sukandarrumidi. 2012. Metodologi Penelitian: Petunjuk Praktis Untuk Peneliti Pemula. Yogyakarta: Gadjah Mada University Press. 